Ethiopian Journal of Environmental Studies \& Management 7 Suppl.: 731 - 743, 2014.

ISSN:1998-0507

doi: http://dx.doi.org/10.4314/ejesm.v7i1.4S

Submitted: July 10, 2014

Accepted: November 06, 2014

\title{
LONGITUDINAL AND CROSS SECTIONAL MIX DATA APPROACH TO IMPACT ASSESSMENT: A CASE STUDY OF COMMUNITY BASED NATURAL RESOURCE MANAGEMENT PROGRAMME, NIGERIA.
}

\author{
${ }^{*}$ COKER, A. A., ${ }^{1}$ OKONJO, C. U., ${ }^{2}$ AJAH, J.0., ${ }^{3}$ ODOEMENA, B.C. ${ }^{2}$ AND IBEAKUZIE, I. 5 \\ ${ }^{1}$ Department of Agricultural Economics and Extension Technology, Federal University of \\ Technology, Minna, P.M.B. 65, Minna, Nigeria \\ ${ }^{2}$ National Programme for Food Security, Wuse-II, FCT, Abuja, Nigeria \\ ${ }^{3}$ Department of Agricultural-Economics and Extension, Faculty of Agriculture, University of \\ Abuja, P.M.B 117, Gwagwalada - Abuja, Federal Capital Territory, Abuja, Nigeria. \\ ${ }^{4}$ International Fund for Agricultural Development (IFAD), IFAD Country Office, Federal Capital \\ Territory, Abuja, Nigeria \\ ${ }^{5}$ Community Based Natural Resource Management Programme, Programme Support Office, \\ Port-Harcourt, Rivers State, Nigeria
}

\begin{abstract}
The study employed longitudinal and cross-sectional mix data approach, "before and after", "with and without" technique in assessing the impact of IFAD Assisted Community Based Natural Resource Management Programme on the socio-economic livelihood, including agricultural productivity, nutrition and job creation potentials of the beneficiaries. Multi-stage sampling was employed to elicit responses from 1,928 households in 64 communities covering 9 participating states in the Niger-Delta Region of Nigeria. The Component Index Analysis, Productivity Index and Double Differencing techniques were employed for data analysis.The Component Index Analysis revealed that even though beneficiaries were of better wealth standing compared to non-beneficiaries, inequalities were observed within the ranks of targeted beneficiaries. Also, direct enterprise productivity impact of programme on beneficiaries was $61.1 \%, 203.3 \%$ and $30.1 \%$ for crops, livestock and fisheries respectively. Programme impact on food consumed was $21.4 \%$ while $84.95 \%$ of the beneficiaries observed improved nutrition compared to $67.7 \%$ under control group. About 47,454 jobs were created with crop sub-sector accounting for about $75 \%$ of the total. The study concluded that the programme impacted on the socio-economic livelihood of beneficiaries, although, impact varied within the rank and file of beneficiaries.
\end{abstract}

Key Words: Impact, Livelihood, Productivity, Nutrition, Job-creation, Socio-economic

\section{Introduction}

Nigeria, being the largest economy in Africa and $26^{\text {th }}$ in the world in terms of magnitude of the economy, with a nominal Gross Domestic Product (GDP) of \$USD 510 billion and an average growth rate of between $6 \%$ and $7 \%$; its per capital GDP, a measure of economic livelihood, ironically stands at

*Corresponding Author: Coker, A.A.

Email: ayodejicoker@futminna.edu.ng
$\$ 2,688$, thus placing it on $121^{\text {st }}$ position in the world economy. Available data from National Bureau of Statistics indicated that relative poverty head count for Nigeria increased sharply from 1980 to 2010 by about 153.7 percent within thirty years (NBS, 2011). Also, the proportion of Nigerians living in poverty is increasing yearly, with

\section{1}


the rural population accounting for 62 percent of this figure. AfDB (2013) also noted that economic growth in Nigeria has not translated into job creation or poverty alleviation. According to AfDB Africa outlook, unemployment increased from $21 \%$ in 2010 to $24 \%$ in 2011 because the sectors driving the economic growth are not high job-creating sectors. It further observed that economic growth was not accompanied by a structural change of the Nigerian economy. Akinwunmi (2011) observed that about 4 million unemployed young people enter the workforce annually. The FGN in its 19992003 economic policy had placed emphasis on poverty reduction and revitalization of the non-oil sectors, particularly agriculture and fisheries while the Rural Development Strategy (RDS) launched in 2001 involved a participatory community development approach with the aim of transferring resources to rural households and developing local communities. IFAD Assisted Community Based Natural Resource Management Programme (CBNRMP-ND) in Niger Delta is a poverty alleviation programme consistent with IFAD's Country Strategic Opportunities Paper (COSOP) for Nigeria and Country's rural and economic development policies. The Programme is a community-based, people centered intervention, with emphasis on the needs of women, youth, core poor households and other vulnerable groups in the nine (9) states of Niger Delta region (Figure 1), namely: Abia, Akwa-Ibom, Bayelsa, Cross River, Delta, Edo, Imo, Ondo and Rivers (CBNRMP-ND, 2010).

The objectives of this study are as follows: (i) assess improvement in the socioeconomic wellbeing of the respondents; (ii) ascertain the impact of the programme on agricultural productivity; (iii) determine the impact of programme on food security and (iv) estimate jobs created by programme. The study is justified given that over the past eight years, CBNRMP-ND carried out a number of activities cutting across programme components and sub-components and as such in view of the impending programme restructuring and redesign, the key stakeholders will be desirous of information to facilitate scaling-up and replication of successful activities while weeding out unsuccessful ones.

Before the commencement of the CBNRMP-ND in 2005, unemployment rate in the Niger-Delta Region like in most parts of Nigeria was spiralling, driven by the wave of millions of young people entering the workforce every year with only a small fraction able to find formal employment. This development arising from long years of neglect resulted in many consequences including, high unemployment for increasing youth of the Niger Delta region, lack of food security, high poverty rate, in-equality, non inclusive and poor economic growth. In view of these developments, various social vices were the order of the day, including cultism, armed robbery, militancy, kidnapping for ransom and assassination. This prompted vital research question from stakeholders following extended period of implementation bordering on the impact of the programme.

The study is justified given that since over 8 years of implementation, numerous socio-economic and livelihood activities have been undertaken by the programme which were expected to have impacted on beneficiaries. Thus, without prejudice to the on-going programme re-structuring and anticipated programme exit, stakeholders are desirous of the impact of the programme for possible replication and up-scaling.

\section{Hypothesis Tested}

The hypothesis put forward under this study were as follows:

Ho: The socio-economic wellbeing of beneficiaries was better than that of nonbeneficiaries of the programme 
Ha: The socio-economic wellbeing of beneficiaries was not better than that of nonbeneficiaries of the programme

\section{Methodology}

Study Area

The Niger Delta agro ecological zone covers the coastal plain and rain forest belt in the southern parts, to derived savanna and highlands in the northern parts. The region has a tropical humid climate characterized by distinct wet and dry seasons. The coastal region and northern region have about 9-10 months and 7-8 months of wet seasons respectively. Rainfall is lowest in the Northern Zone (less than $170 \mathrm{~mm}$ ) and highest in the forest or coastal zone (above

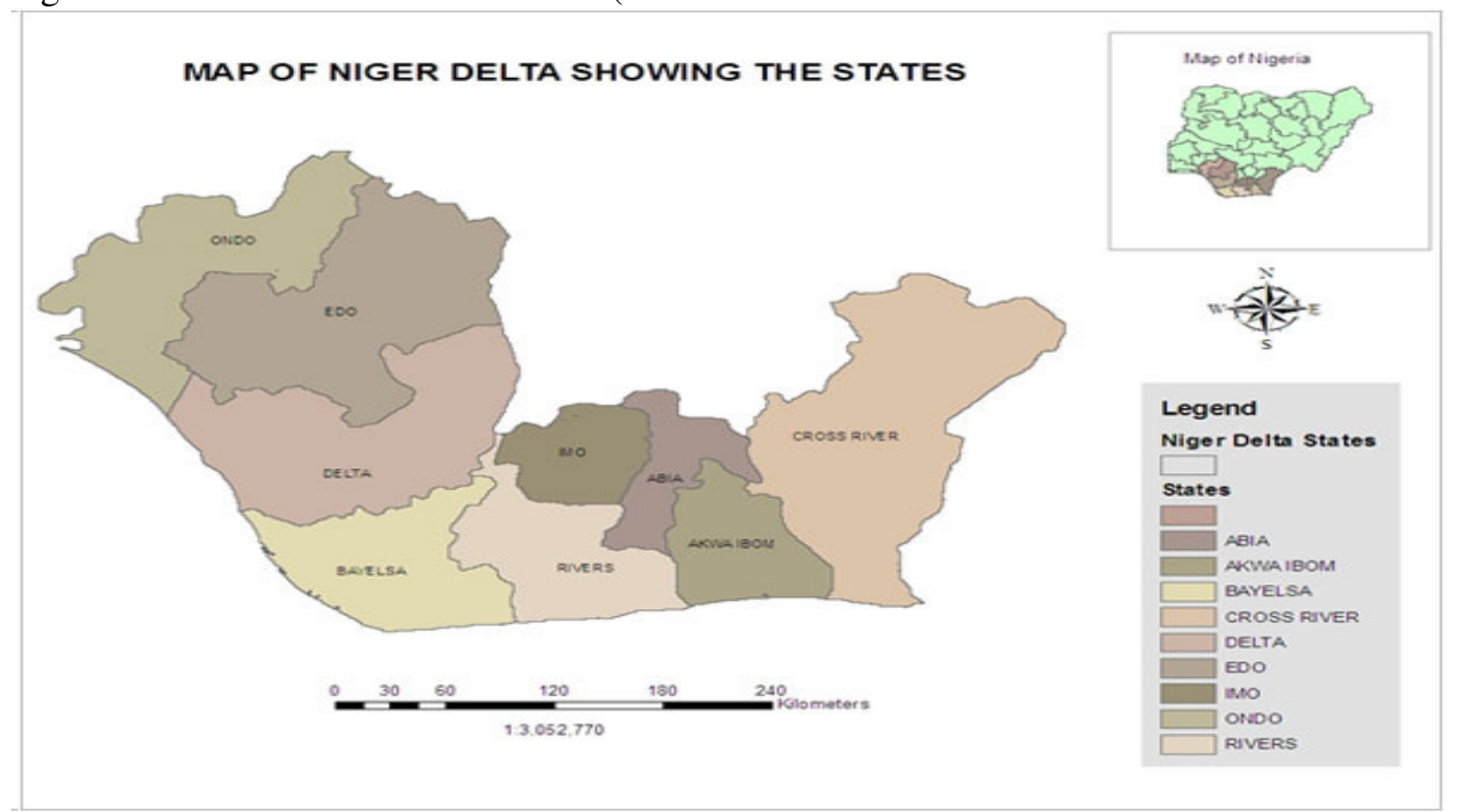

Source: Robinson, T. S. (2009). Challenges of Mapping Applications in Health and Academic Research in the underdeveloped World - Case Study of The Niger Delta Region (Nigeria)

Figure 1: Map of Niger-Delta Region, Nigeria

\section{Sampling Design and Data Collection}

Theory based Impact evaluation technique, quantitative, evidence-based and qualitative approaches were applied for the study. The data were gathered through direct observations, focus group discussions through in-depth interviews and
$(3,000 \mathrm{~mm})$, with the dry months having less than $60 \mathrm{~mm}$ of rainfall. The driest months have less than $29 \mathrm{~mm}$ of rainfall. Dry season starts in November and terminates by February. At this time, wind becomes dry and dusty resulting in harmattan haze which characterizes the period. There is very little or no rainfall with cooler nights, low relative humidity, less cloud cover and increased incipient solar radiation resulting in hotter days (Figure 1). Mean annual temperature of the region is between $21^{\circ} \mathrm{C}$ and $29^{\circ} \mathrm{C}$ on the Hilly and Plateau areas of the region. Annual rainfall distribution varies throughout the region (CBNRMP, 2008). 
Longitudinal and Cross Sectional Mix Data Approach to Impact Assessment................COKER et al.

participating and non-participating LGAs and communities in each of the programme states. The first stage of sampling covers the random selection of 3 - 4 LGAs in each state (2 each from the participating and nonparticipating LGAs). For the second stage of sampling, a community was randomly selected from beneficiary and nonbeneficiary communities in each of the selected LGA (Figure 2). Thereafter, 30 households were selected using the random walk method in each of the selected communities, and enumerators were instructed to ensure that at least $30 \%$ of the households interviewed were female-headed or belonged to vulnerable and/or physically challenged category. In each state, 6 - 8 communities were ultimately selected for community/focus group interview and 180 240 households for household interview. A total of 64 communities and 1,928 households were interviewed in the 9 states covered. While households in survey were identified with the assistance of the village/community leaders, communities covered in the survey had their geocoordinates determined by the Global Positioning System (GPS) instrument (Figure 2).

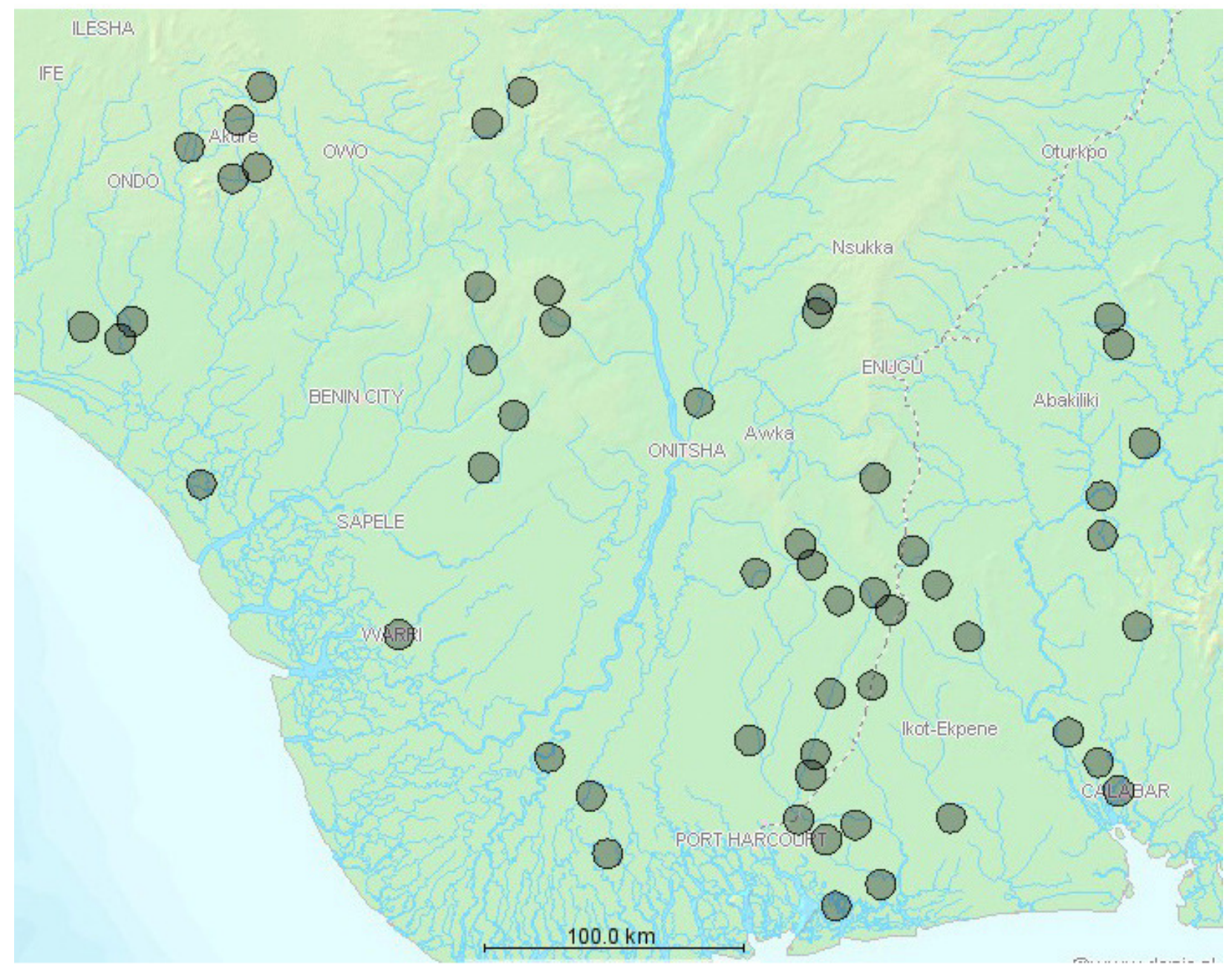

Figure 2: GPS Locations of Sampled Communities, 2014 


\section{Analytical Technique and Model Specification \\ To effectively capture the requirements of} the study's objectives, descriptive and inferential statistics were employed to deduce and explain programme's impact on participants. This entailed content analysis, double differencing, graphical and tabular presentations, the use of t-test to ascertain significance of impact. The productivity index and principal component analytical tools were also used to deduce productivity and assess level of improvement in socioeconomic well-being of respondents.

\section{Model Specification:}

Principal Component Analysis Model

This study employed Principal Component Analysis (PCA) used by Filmer and Prichette, 1998 and Prakongsai (2007) to compare improvement in socio-economic well-being of sampled programme beneficiaries and non-beneficiaries (Objective 1). The Principal Component Analysis (PCA) is very similar to factor analysis. According Prakongsai (2007), the technique can determine the weight as a factor score for each asset variable. It seeks a linear combination of variables such that maximum variance is extracted from variables. It then removes this variance and seeks a second linear combination which explains the maximum proportion of remaining variance, and so on. This is called the Principal Axis Method and results in orthogonal (uncorrelated) factors. The output of the asset index obtained from PCA for each household asset can be obtained with the following formula:

$A \mathrm{j}=\mathrm{f1} *(\mathrm{a} \mathrm{j1-a1)} /(\mathrm{s} 1)+\ldots+\mathrm{f} \mathrm{n} *(\mathrm{ajn}-\mathrm{an}) /$ (sn)

\section{Where:}

$\boldsymbol{A} \boldsymbol{j}$ is an asset index for each household ( $\mathrm{j}$ $=1, \ldots \ldots, \mathrm{n})$ $f i$ is the scoring factor for each durable asset of household $(i=1, \ldots \ldots, n)$

aji is the $\mathrm{i}$ th asset of $\mathrm{j}$ th household ( $\mathrm{i}, \mathrm{j}$ $=1, \ldots \ldots, \mathrm{n}$ )

$\boldsymbol{a} \boldsymbol{i}$ is the mean of $\mathrm{i}$ th asset of household (i $=1, \ldots \ldots, \mathrm{n}$ )

$s i$ is the standard deviation of $i$ th asset of household $(\mathrm{i}=1, \ldots \ldots, \mathrm{n})$

$\boldsymbol{Z}$ is the standardized variables of each household

The Asset Index analysis was used to compare improvement in socio-economic well-beings of sampled programme beneficiaries and non-beneficiaries. Specifically, the analysis was used as a proxy to measure household living standards, given peculiar problems in generating accurate household income data.

\section{Productivity Index}

This tool was employed to ascertain productivity. The model was specified thus:

Productivity $(\mathrm{Kg} / \mathrm{Ha})=\mathrm{P}_{1} \quad(\mathrm{Kg}) / \mathrm{A}_{1}$ (Ha)

\section{Where:}

$\mathrm{P}_{1}=$ Output of $\mathrm{i}_{\text {th }}$ Farmer in Kilogram

$\mathrm{A}_{1}=$ Area of Farm-land Cultivated in Hectares

\section{Double Differencing $\left(\mathrm{DD}_{2}\right)$ Model}

$\mathrm{D}_{1 \text { Yrlp }}-\mathrm{D}_{1 \text { Yrnp }}=\mathrm{DD}_{\mathrm{b}}$

$\mathrm{D}_{1 \text { Yrlc }}-\mathrm{D}_{1 \text { Yrnc }}=\mathrm{DD}_{\mathrm{c}}$

$\mathrm{DD}_{\mathrm{b}}-\mathrm{DD}_{\mathrm{c}}=\mathrm{DD}_{2}$

\section{Where:}

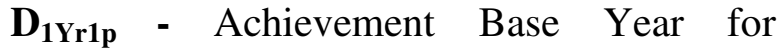
Programme Beneficiaries

D $_{\text {YYrnp }}$ - Achievement Assessment Year for Programme Beneficiaries

DD $_{\mathbf{b}}$ - Difference between Base Year and Assessment Year for Programme Beneficiaries 
D1Yr1c - Achievement Base Year for Control Group

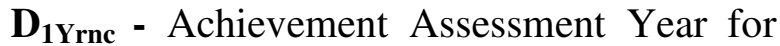
Control Group

DD - Difference between Base Year and Assessment Year for Control

$\mathrm{DD}_{2}$ - Difference between $\mathrm{DD}_{\mathrm{b}}$ and $\mathrm{DD}_{\mathrm{c}}$

\section{Results and Discussions}

Improvement in Socio-economic Well-being of Programme Beneficiaries

In line with a priori expectations, households with high economic status tended to have assets with high factor scores while those with low factor scores are associated with low economic status. The asset-based measure depicts a household's long-run economic status and does not necessarily account for short term fluctuations in economic well-being or economic shock. The index takes into consideration the distribution of assets in the participating and non-participating communities in order to reflect economic conditions of each group (Beneficiaries or Non-beneficiaries). In all, 22 assets (home and production) were considered for analysis (Table1). A higher Asset Index represents a higher level of livelihood improvement.

Table 1: Assets ownership and Index Score in 2013

\begin{tabular}{lllll}
\hline \multirow{2}{*}{ Assets } & \multicolumn{2}{l}{ Owning Assets $(\%)$} & \multicolumn{2}{l}{ Asset Index score } \\
\cline { 2 - 5 } & Beneficiaries & Non-Beneficiaries & Beneficiaries & Non-Beneficiaries \\
\hline Radio & 78.4 & 78.9 & 0.1472 & 0.2597 \\
Television & 70.4 & 61.7 & 1.0450 & 0.2480 \\
Refrigerator & 34.1 & 26.1 & 0.1830 & 0.0261 \\
Dvd/vcd & 66.8 & 51.1 & -0.2492 & 0.2668 \\
Gsm handset & 78.1 & 71.7 & 2.4995 & 0.1958 \\
Landline phone & 6.2 & 6.1 & 0.2786 & 0.6049 \\
Bicycle & 30.4 & 30.7 & -0.0172 & 0.4693 \\
Motorcycle & 36.0 & 32.9 & 1.0372 & 0.5810 \\
Car & 10.1 & 7.5 & 7.7351 & -0.2326 \\
Truck/lorry & 0.9 & 1.2 & 5.8169 & 1.5846 \\
Pickup van & 1.4 & 1.5 & 1.2631 & 1.2886 \\
Storage facility & 1.3 & 1.8 & 0.6676 & 1.1456 \\
Water pump & 12.6 & 10.5 & 4.6162 & -0.6592 \\
Tractor & 1.3 & 1.8 & 7.4900 & 2.2240 \\
Tractor implements & 1.0 & 2.2 & 2.4570 & 2.0004 \\
B-hole/t-well/w-bores & 6.4 & 2.7 & 2.3611 & 0.4086 \\
Dugout canoe & 6.4 & 2.7 & 4.3674 & 1.1962 \\
Motorized engine boat & 3.5 & 4.8 & 5.6240 & 1.6550 \\
Lumberjack & 1.5 & 2.3 & 1.8172 & 1.6867 \\
Cast net & 9.7 & 10.1 & 1.9612 & 1.2455 \\
Crop proc. Machine & 8.5 & 4.8 & 0.2994 & 0.2963 \\
Personal electr. Source & 45.7 & 33.4 & 2.3 & 0.2806 \\
Mean & 23.2 & 20.3 & 2.4 & 0.8 \\
\hline
\end{tabular}

The analysis showed that beneficiaries had more production related assets compared to non-beneficiaries (Figure 3). Households that owned assets such as trucks, pick -up van, tractor parts and Lumber-jack had higher
Asset Index Score than those without it. The result further indicates that the programme beneficiaries, given their wealth status advantage may be in a position to liquidate asset in order to access food compared to 
non-beneficiaries. This result is in tandem with findings of the external evaluation of the National Special Programme on Food security which observed improved access of programme beneficiaries to irrigation facilities and infrastructure compared to the non-beneficiaries, even though access to processing asset was almost equal for the two groups (PCU, 2008). CBARDP (2013) also observed increment in assets like radio, television, mobile phones, music sets, beddings and house properties for programme beneficiaries.

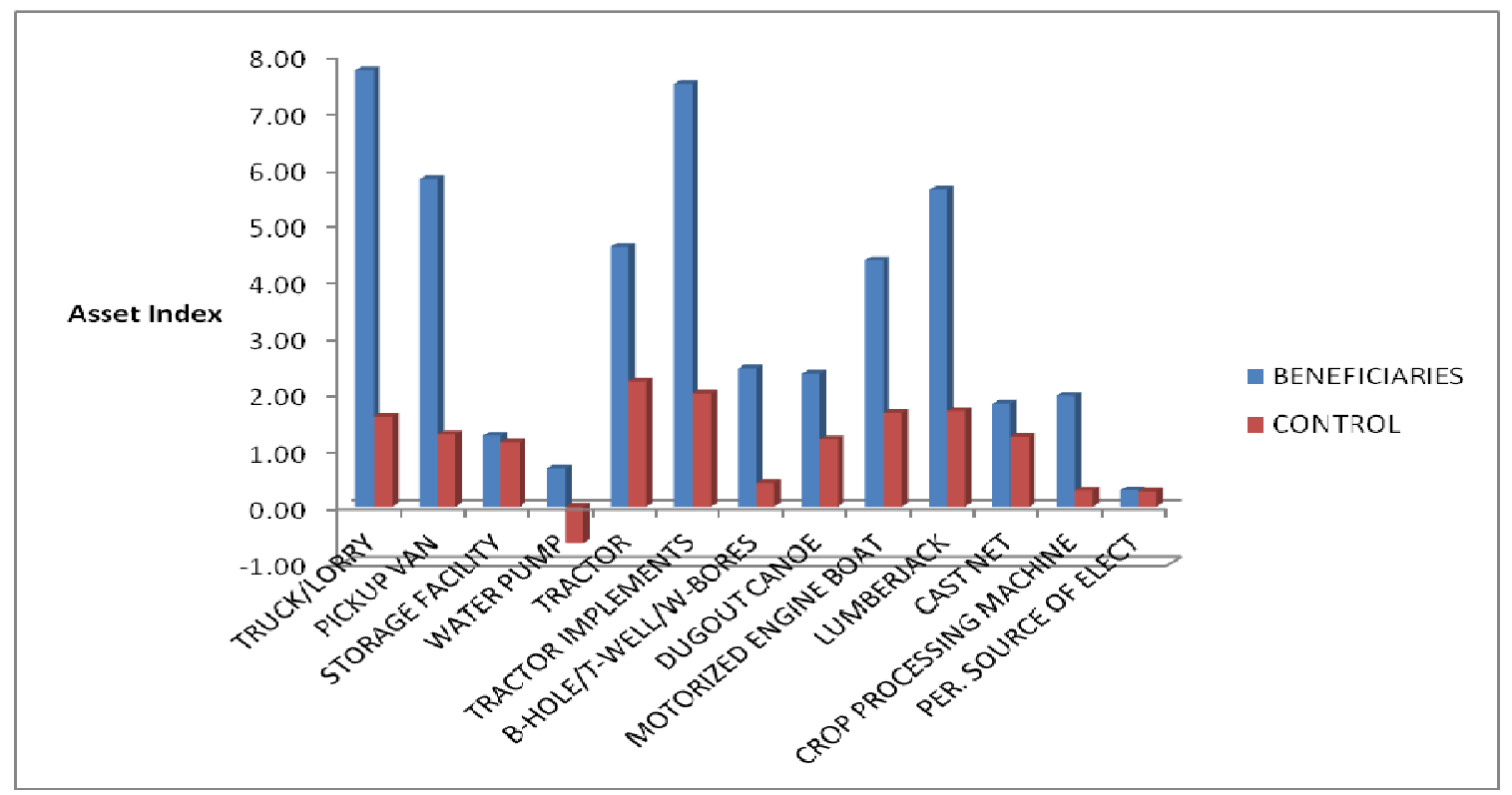

Figure 3: Status of production asset index between beneficiaries and control in 2013

To further ascertain presence of inequality and assess the trend of well-being among programme beneficiaries, sampled households were categorized into five quintiles from the core poor to the fairly well off using principal component analysis approach. The review of the 2013 component analysis results showed that individuals in the fifth quintile unambiguously show much higher level of wealth than the rest of beneficiaries' population. For instance, $69.7 \%, 65.2 \%$ and $55.6 \%$ of those in fifth quintile under the programme beneficiaries owned water pump, crop processing equipment and refrigerator respectively compared to $0 \%, 3.0 \%$ and $1.6 \%$ obtained in the first quintile during 2013 (Table 2). The ensuing results revealed that there were still some levels of inequalities within targeted beneficiaries of the programme. Even though beneficiaries of the programmes were of better wealth standing compared to non-beneficiaries as reflected by increasing and high average index score; the well-being within the core poor (first quintile) which is supposed to be the primary target of the programme was not superior to that of nonbeneficiaries. The aforementioned result confirms the null hypothesis of this study which stated that the well-being of the beneficiaries was better than that of nonbeneficiaries. 
Table 2: Beneficiaries' Asset Index Quintiles

\begin{tabular}{llllll}
\hline Assets & 1st & 2nd & 3rd & 4th & 5th \\
& Quintile & Quintile & Quintile & Quintile & Quintile \\
\hline Radio & 0.9 & 29.8 & 20.7 & 23.2 & 25.4 \\
Television & 0 & 1.3 & 7.3 & 41.5 & 49.8 \\
Refrigerator & 0 & 0 & 1.7 & 17.6 & 80.7 \\
Dvd/vcd & 0 & 0.8 & 9.5 & 36.4 & 53.4 \\
Gsm handset & 0 & 4.1 & 20.5 & 31.4 & 44 \\
Landline phone & 11.1 & 11.1 & 33.3 & 33.3 & 11.1 \\
Bicycle & 4.6 & 15.2 & 23.4 & 20.8 & 36 \\
Motorcycle & 0 & 1.3 & 20.9 & 21.5 & 56.3 \\
Car & 0 & 0 & 2.8 & 8.3 & 88.9 \\
Truck/lorry & 0 & 0 & 0 & 0 & 100 \\
Pickup van & 0 & 0 & 12.5 & 12.5 & 75 \\
Storage facility & 0 & 0 & 15.6 & 28.1 & 56.2 \\
Water pump & 0 & 0 & 0 & 18.2 & 81.8 \\
Tractor & 0 & 0 & 100 & 0 & 0 \\
B-hole/t-well/w-bores & 0 & 0 & 0 & 6.7 & 93.3 \\
Dugout canoe & 14.6 & 7.3 & 24.4 & 29.3 & 24.4 \\
Motorized engine boat & 0 & 11.1 & 44.4 & 11.1 & 33.3 \\
Lumberjack & 0 & 0 & 40 & 20 & 40 \\
Cast net & 12.2 & 12.2 & 34.7 & 32.7 & 8.2 \\
Crop processing machine & 0 & 0 & 12.5 & 31.2 & 56.2 \\
Personal electricity source & 0 & 0 & 7.1 & 18.4 & 74.5 \\
\hline
\end{tabular}

\section{Impact on Livelihood}

The study revealed that direct average productivity impact on programme beneficiaries' yields stood at an average of $61.1 \%$ in 2013 while it varied from about $45.3 \%$ for plantain to $103.5 \%$ for cassava (Table 3). Across board, cassava productivity was about $25 \mathrm{mt} / \mathrm{ha}$ compared to about $12 \mathrm{mt} / \mathrm{ha}$ by non-beneficiaries. Z-test of significance indicated a significant difference between the cassava productivity of the two populations under study. Similarly, average yield for rice was $3 \mathrm{mt} / \mathrm{ha}$ compared to $2 \mathrm{mt} / \mathrm{ha}$ reported by non-beneficiaries (Figure 4). This is higher than the $38 \%$ increase observed for rice as a result of the intervention of Community Based Agricultural and Rural Development Programme in Nigeria
(CBARDP, 2013). In Ondo State, for example, yield of cassava was higher as about 30mt/ha was recorded in some participating communities. This may not be unconnected to the trainings and improved technologies introduced by programme through Songhai Technology Transfer Station, National Root Crop Research Institute, Umudike and activities of extension components of the States' Agricultural Development Programmes. Generally, productivity figures obtained under the programme for maize $(2.57 \mathrm{mt} / \mathrm{ha})$, rice $(2.93 \mathrm{mt} / \mathrm{ha})$, cassava $(25.3 \mathrm{mt} / \mathrm{ha})$ and yam $(19.45 \mathrm{mt} / \mathrm{ha})$ were higher than the 1.72 $\mathrm{mt} / \mathrm{ha}, 2.24 \mathrm{mt} / \mathrm{ha}, 13.62 \mathrm{mt} / \mathrm{ha}$ and 13.45 $\mathrm{mt} / \mathrm{ha}$ national agricultural production figures obtained for Nigeria (NPFS, 2010). 
Table 3: Impact of CBNRMP-ND on beneficiaries crop productivities ( $\mathrm{Kg} / \mathrm{ha})$

\begin{tabular}{llllllllll}
\hline Crops & \multicolumn{2}{c}{2007} & \multicolumn{9}{c}{2012} & \multicolumn{6}{c}{2013} \\
& $\begin{array}{l}\text { Benefici } \\
\text { ary }\end{array}$ & $\begin{array}{l}\text { Non- } \\
\text { Benefi- } \\
\text { ciary }\end{array}$ & $\begin{array}{l}\% \\
\text { Impact }\end{array}$ & $\begin{array}{l}\text { Benefici } \\
\text { ary }\end{array}$ & $\begin{array}{l}\text { Non- } \\
\text { Benefi- } \\
\text { ciary }\end{array}$ & $\begin{array}{l}\% \\
\text { Impact }\end{array}$ & $\begin{array}{l}\text { Benefici } \\
\text { ary }\end{array}$ & $\begin{array}{l}\text { Non- } \\
\text { Benefi- } \\
\text { ciary }\end{array}$ & $\begin{array}{l}\% \\
\text { Impact }\end{array}$ \\
\hline Maize & 1,662 & 1,623 & 2.40 & 1,728 & 1,643 & 5.17 & 2,571 & 1,684 & 52.16 \\
Rice & 1,840 & 1,843 & -0.16 & 2,314 & 1,894 & 22.18 & 2,933 & 1,921 & 52.68 \\
Cassava & 12,044 & 12,012 & 0.27 & 19,014 & 12,082 & 57.37 & 25,324 & 12,442 & 103.54 \\
Yam & 11,265 & 11,476 & -1.84 & 16,542 & 11,662 & 41.85 & 19,453 & 11,724 & 65.92 \\
Vegetabl & 983 & 987 & & 1,404 & 1,004 & & 1,822 & 1,246 & \\
es & & & -0.41 & & & 39.84 & & & 46.23 \\
Plantain & 5,512 & 5,541 & -0.52 & 6,321 & 5,620 & 12.47 & 8,214 & 5,652 & 45.33 \\
Mean & & & -0.04 & & & 29.81 & & & 61.06 \\
\hline
\end{tabular}

Evidence from Table 3 also reveals some marginal increases in the productivity among the nonbeneficiaries for most crops under consideration. The outreach impact is expected to be greater considering intra-communal innovation diffusion and provision of social amenities like roads, which eased intra-communal interaction and farmer-to-farmer technology dissemination.

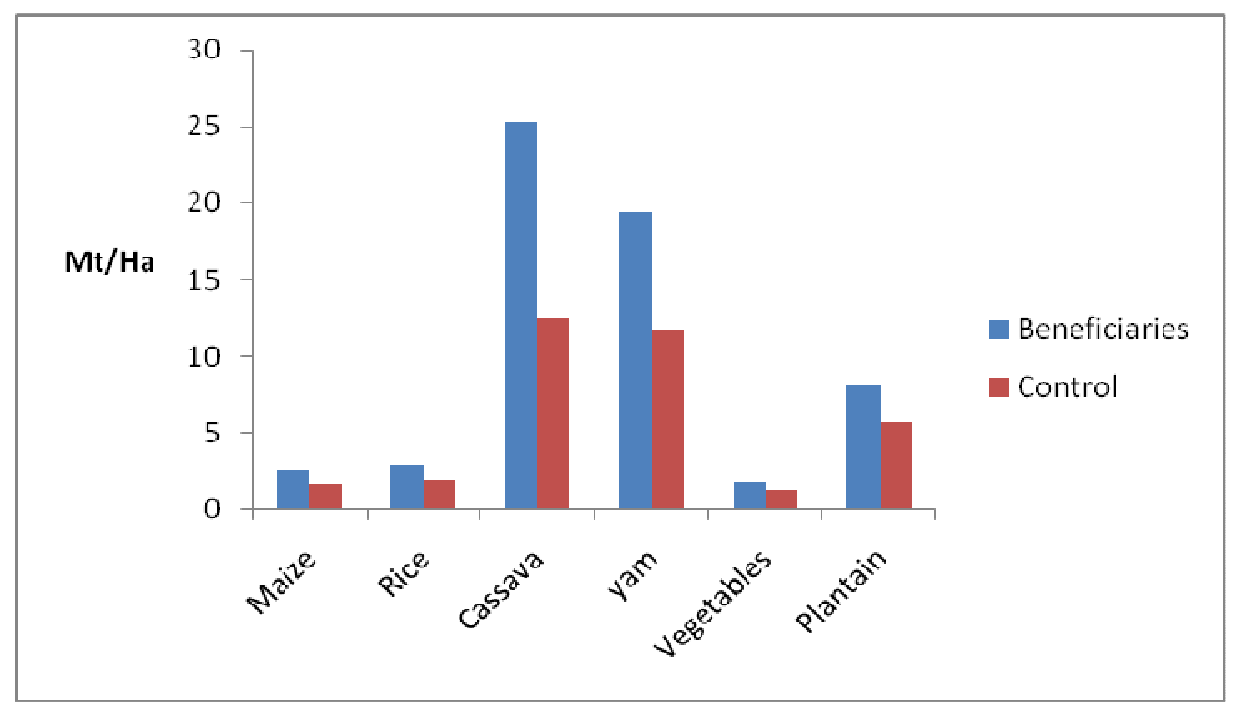

Figure 4: Impact on crop productivity as at 2013

With respect to livestock production, the positive impact was over $100 \%$ for goat, pig and poultry enterprises (Table 4). The impact was largest under poultry, thus showing the intensity of support for poultry production under the programme. The result differ from that obtained by PCU (2008) which observed that percentage of non beneficiary households (38\%) that produced poultry, goat and sheep exceeded that of the beneficiary households $(30 \%)$ under the National Programme for Food Security in Nigeria; but noted that while the former maintained free range system the latter embraced intensive production system. 
Table 4: Livestock production impact: mean number of livestock produced and sold by households

\begin{tabular}{|c|c|c|c|c|c|c|c|c|c|}
\hline \multirow[b]{2}{*}{$\begin{array}{l}\text { Livestock } \\
\text { Type }\end{array}$} & \multicolumn{3}{|l|}{2007} & \multicolumn{3}{|l|}{2012} & \multicolumn{3}{|l|}{2013} \\
\hline & $\begin{array}{l}\text { Benefi- } \\
\text { ciaries }\end{array}$ & $\begin{array}{l}\text { Non- } \\
\text { Benefi- } \\
\text { ciaries }\end{array}$ & $\begin{array}{l}\% \\
\text { Impact }\end{array}$ & $\begin{array}{l}\text { Benefi- } \\
\text { ciaries }\end{array}$ & $\begin{array}{l}\text { Non- } \\
\text { Benefi- } \\
\text { ciary }\end{array}$ & $\begin{array}{l}\% \\
\text { Impact }\end{array}$ & $\begin{array}{l}\text { Benefi- } \\
\text { ciaries }\end{array}$ & $\begin{array}{l}\text { Non- } \\
\text { Benefi- } \\
\text { ciaries }\end{array}$ & $\begin{array}{l}\% \\
\text { Impact }\end{array}$ \\
\hline Goats & 2 & 3 & -33 & 4 & 4 & 0 & 5 & 2 & 150 \\
\hline Sheep & 1 & 1 & 0 & 1 & 2 & -50 & 3 & 3 & 0 \\
\hline Pigs & 11 & 5 & 120 & 37 & 4 & 825 & 28 & 5 & 460 \\
\hline Poultry & 11 & 12 & -8 & 695 & 29 & 2296 & 771 & 35 & 2103 \\
\hline Mean & & & 19.7 & & & 258.3 & & & 203.3 \\
\hline
\end{tabular}

The impact on beneficiaries' fishery production was over $20 \%$ for both aquaculture and artisanal interventions as at the close of 2013 (Table 5).

Table 5: Mean quantity of fish produced and sold by households (kg)

\begin{tabular}{|c|c|c|c|c|c|c|c|c|c|}
\hline \multirow[b]{2}{*}{$\begin{array}{l}\text { Fishery } \\
\text { Enterprise }\end{array}$} & \multicolumn{3}{|l|}{2007} & \multicolumn{3}{|l|}{2012} & \multicolumn{3}{|l|}{2013} \\
\hline & $\begin{array}{l}\text { Benefi- } \\
\text { ciaries }\end{array}$ & $\begin{array}{l}\text { Non- } \\
\text { Benefi- } \\
\text { ciaries }\end{array}$ & $\begin{array}{l}\% \\
\text { Impact }\end{array}$ & $\begin{array}{l}\text { Benefi- } \\
\text { ciaries }\end{array}$ & $\begin{array}{l}\text { Non- } \\
\text { Benefi- } \\
\text { ciary }\end{array}$ & $\begin{array}{l}\% \\
\text { Impact }\end{array}$ & $\begin{array}{l}\text { Benefi- } \\
\text { ciaries }\end{array}$ & $\begin{array}{l}\text { Non- } \\
\text { Benefi- } \\
\text { ciaries }\end{array}$ & $\begin{array}{l}\% \\
\text { Impact }\end{array}$ \\
\hline Aquaculture & $1,472.3$ & 781.0 & 88.5 & $1,488.85$ & $1,110.95$ & 34.0 & $1,647.83$ & $1,314.48$ & 25.3 \\
\hline $\begin{array}{l}\text { Artisanal } \\
\text { Mean }\end{array}$ & $2,376.1$ & $1,652.6$ & $\begin{array}{l}43.8 \\
66.1\end{array}$ & $2,524.21$ & $1,672.58$ & $\begin{array}{l}50.9 \\
42.5\end{array}$ & $2,184.53$ & $1,619.5$ & $\begin{array}{l}34.9 \\
30.1\end{array}$ \\
\hline
\end{tabular}

\section{Impact on Nutrition and Food Security}

Normally, the focus of nutrition and food security impact assessment is on accessibility, affordability, sustainability and quality of nutrition, rather than the quantity. However, given that data collection domain was the household, assessment focused largely on quantity and number of meals household consumed. The assessment also ignored food purchased and consumed outside the home. The study revealed that the average household in both the participating and non-participating groups had at least 3 meals a day (Table 6). The impact of programme on food consumed is depicted by outcome of the double differencing result, where positive changes in quantities were observed for rice, garri/fufu, beans and plantain consumed by household per week (Table 7). Furthermore, with respect to quality and composition of household meals, there were positive impacts of programme for eggs, milk, vegetables and fruits consumption (Table 8). These categories of food items are rich in vitamins $\mathrm{A} \& \mathrm{C}$ and many minerals such as calcium, potassium and zinc; some of these vitamins serve as sources of fibre for a healthy digestive system. The results further justify the need for intensification of farm diversification activities involving livestock and fisheries production. Table 9 further revealed that about $85 \%$ of the households interviewed affirmed that their nutritional status changed compared to $68 \%$ that reported for the non-beneficiaries (Figure 5). This result is in line with the outcome of the IFAD Assisted Community Based Agricultural and Rural Development Programme impact Assessment Study which observed improved nutrition for programme beneficiaries including children compared to the non beneficiaries (CBARDP, 2013). 
Table 6: Number of meals taken daily by the households

\begin{tabular}{lllll}
\hline \multirow{2}{*}{ State } & 2007 & & 2013 & \\
\cline { 2 - 5 } & Beneficiaries & $\begin{array}{l}\text { non- } \\
\text { beneficiaries }\end{array}$ & Beneficiaries & $\begin{array}{l}\text { non- } \\
\text { beneficiaries }\end{array}$ \\
\hline Abia & 2 & 3 & 3 & 3 \\
Akwa Ibom & 3 & 2 & 3 & 3 \\
Bayelsa & 3 & 3 & 3 & 3 \\
Cross River & 2 & 3 & 3 & 3 \\
Delta & 3 & 3 & 3 & 3 \\
Edo & 3 & 3 & 3 & 3 \\
Imo & 3 & 2 & 3 & 3 \\
Ondo & 3 & 3 & 3 & 3 \\
Rivers & 3 & 3 & 3 & 3 \\
Mean & 3 & 3 & 3 & 3 \\
\hline
\end{tabular}

Table 7: Quantity of food items consumed per week

\begin{tabular}{|c|c|c|c|c|c|c|c|}
\hline \multirow[b]{2}{*}{ Crop } & \multicolumn{2}{|c|}{ Beneficiaries } & \multicolumn{4}{|c|}{ Non-beneficiaries } & \multirow{2}{*}{$\begin{array}{l}\text { Double } \\
\text { Difference } \\
\text { (\% impact) }\end{array}$} \\
\hline & 2007 & 2013 & $\begin{array}{l}\% \\
\text { Change }\end{array}$ & 2007 & 2013 & $\begin{array}{l}\% \\
\text { Change }\end{array}$ & \\
\hline Rice & 10.82 & 16.61 & 53.5 & 10.83 & 13.53 & 24.9 & 28.6 \\
\hline Garri/Fufu & 15.42 & 19.08 & 23.7 & 22.11 & 23.85 & 7.9 & 15.9 \\
\hline Yam & 8.84 & 11.54 & 30.5 & 12.50 & 16.77 & 34.2 & -3.6 \\
\hline Beans & 6.97 & 11.02 & 58.1 & 7.74 & 10.17 & 31.4 & 26.7 \\
\hline Plantain & 7.60 & 11.30 & 48.7 & 8.49 & 9.26 & 9.1 & 39.6 \\
\hline Mean & & & 42.9 & & & 21.5 & 21.4 \\
\hline
\end{tabular}

Table 8: No of meals with food items

\begin{tabular}{lcccccccc}
\hline Food & \multicolumn{3}{c}{ Beneficiaries } & \multicolumn{3}{c}{ Non-Beneficiaries } & Double & \% Impact \\
\cline { 2 - 7 } & 2007 & 2013 & Change & 2007 & 2013 & Change & Difference & \\
\hline Meat/Fish & 1.95 & 2.14 & 0.19 & 1.86 & 2.2 & 0.34 & -0.15 & -44.12 \\
Eggs & 0.61 & 1.02 & 0.41 & 0.67 & 0.96 & 0.29 & 0.12 & 41.38 \\
Milk & 0.72 & 1.12 & 0.4 & 0.76 & 1.01 & 0.25 & 0.15 & 60.00 \\
Vegetables/Fruits & 1.96 & 2.35 & 0.39 & 1.8 & 2 & 0.2 & 0.19 & 95.00 \\
Rice/Yam/Garri/Fufu & 1.99 & 2.08 & 0.09 & 2.02 & 2.16 & 0.14 & -0.05 & -35.71 \\
& & & & & & 0.26 & 100 & \\
\hline
\end{tabular}

Table 9: Assessment of the nutritional status of household members (\%)

\begin{tabular}{llll}
\hline Indicators & Beneficiaries & non-beneficiaries & $\%$ Difference \\
\hline Improved & 84.9 & 67.7 & 20.26 \\
Declined & 5.4 & 9.1 & -68.52 \\
Unchanged & 9.1 & 22.6 & -148.35 \\
\hline
\end{tabular}




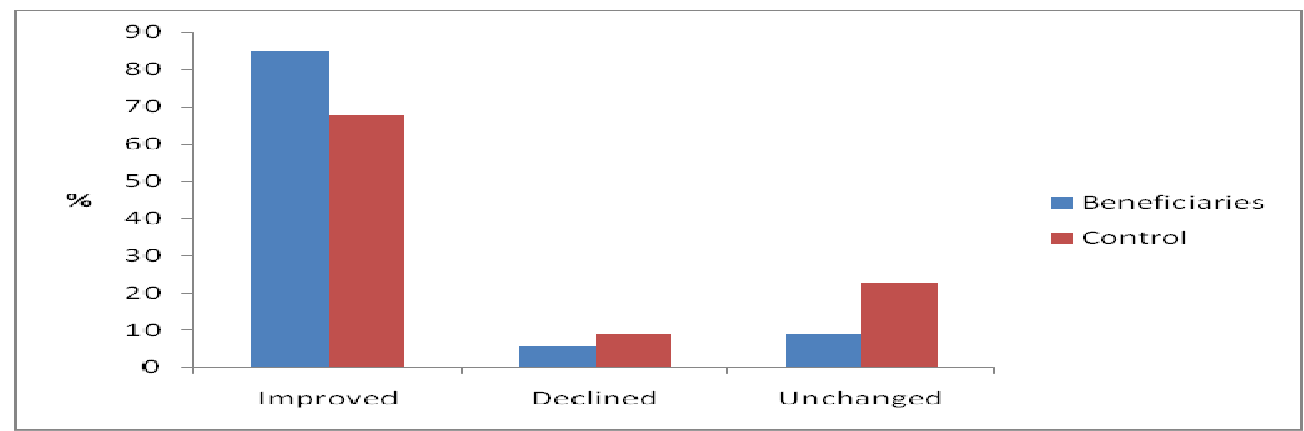

Figure 5: Assessment of nutritional status of household members

\section{Job Creation}

In line with IFAD's definition, the creation of job within the agricultural sector is premised on any task which an individual or person performs continuously for twenty one days for the purpose of earning a wage (IFAD, 2007). The study showed that the programme impacted significantly on employment, which was put at 47,454 from all enterprises supported. The percentage impact of thematic enterprise on total employment, ranged from about $1 \%$ under nontimber and forest products to $75 \%$ for crop sub-projects (Table 10 and Figure 6). The employment created equally had some multiplier effects on the implementing states and country through poverty reduction. The employment effects could even be higher if all the enterprises were taken as completed rather than on-going concern.

Table 10: Estimated impact of programme on employment

\begin{tabular}{lcc}
\hline Enterprises & $\begin{array}{c}\text { Employment created (No } \\
\text { of jobs) }\end{array}$ & \% Total \\
\hline Crops & 35,689 & 75.21 \\
Livestock & 3,210 & 6.76 \\
Fisheries & 4,263 & 8.98 \\
Agro-processing & 2871 & 6.05 \\
Non-Timber and Forest Products & 351 & 0.74 \\
Non-farm enterprises & 1070 & 2.25 \\
\hline Aggregate & 47,454 & 100 \\
\hline
\end{tabular}

Source: CBNRMP-ND States

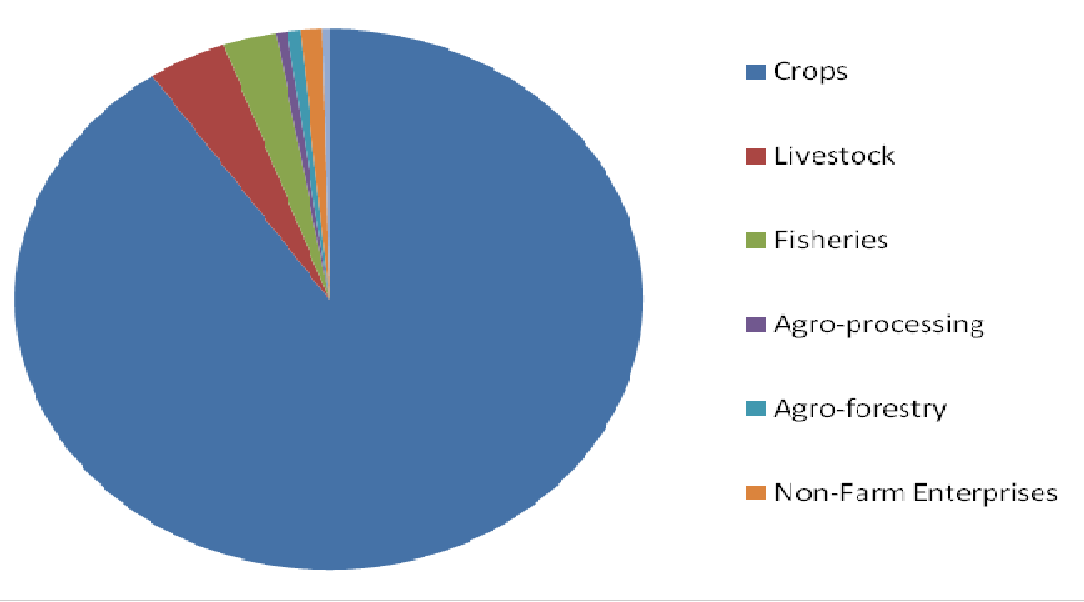

Figure 6: Impact of programme on employment 
Conclusion and Recommendations

It is recommended that the programme strengthens its nutrition related sensitization, encourage the consumption of protein rich food items, such as meat and fish and further support the adoption of technology enhancing inputs, through effective participation under the on-going Agricultural Transformation Agenda propelled Growth Enhancement Support Scheme and sustained linkage with the technology transfer station like Songhai. Focus on profitable production enterprises, while encouraging diversification will ensure long run enterprise sustainability, improve beneficiaries' income, purchasing power and livelihood.

\section{References}

Federal Ministry of Agriculture and Rural Development (FMARD), (2010). Agricultural Production Survey Report. Abuja-Nigeria.

Community Based Agricultural and Rural Development Programme (CBARDP), (2013). Impact Assessment Report. Katsina, Nigeria.

Community Based Natural Resource Management Programme (CBNRMPND), (2014). Impact Assessment Draft Report, Port Harcourt, Rivers State, Nigeria

Community Based Natural Resource Management Programme (CBNRMPND), (2010). Mid Term Review Report, Port Harcourt, Rivers State, Nigeria
International Fund for Agricultural Development (IFAD), (2002). Nigeria Community-Based Natural Resource Management Programme Niger Delta (CBNRMP-ND) Appraisal Report. Rome.

International Fund for Agricultural Development (IFAD), (2007). Result and Impact Management System (RIMS). First and Second Level Results Handbook.

National Bureau of Statistics (NBS), (2012). Nigeria Poverty Profile 2010. Federal Capital Territory, Abuja, Nigeria.

National Programme for Food Security (NPFS), (2010), Agricultural Production Survey Report. Abuja, Nigeria.

Prakongsai, P. (2007). An Application of Asset Index for Measuring Household Living Standard in Thailand. International Health Program, Thailand. Projects Coordinating Unit (PCU), (2008). Evaluation of National Special Programme on Food Security. (NSPFS:2002-2006). Impact Study Report. Abuja, Nigeria.

Robinson, T.S. (2009). Challenges of Mapping Applications in Health and Academic Research in the underdeveloped World - Case Study of the Niger Delta Region (Nigeria). Retrieved from http: // www.esensetechnologies.com. 